\title{
Newly identified mutations at the CSN1S1 gene in Ethiopian goats affect casein content and coagulation properties of their milk
}

\author{
T. A. Mestawet, ${ }^{*} \dagger^{1}$ A. Girma, $\dagger$ T. Ådnøy, $\ddagger$ T. G. Devold, ${ }^{*}$ and G. E. Vegarud ${ }^{*}$ \\ *Department of Chemistry, Biotechnology and Food Sciences, Norwegian University of Life Sciences, Norway, PO Box 5003,1432 Ås, Norway \\ †Department of Animal and Range Sciences, Hawassa University, PO Box 05, Hawassa, Ethiopia \\ ‡Department of Animal and Aquacultural Sciences, Norwegian University of Life Sciences, Norway, PO Box 5003, 1432 Ås, Norway
}

\section{ABSTRACT}

Very high casein content and good coagulation properties previously observed in some Ethiopian goat breeds led to investigating the $\alpha_{\mathrm{s} 1}$-casein (CSN1S1) gene in these breeds. Selected regions of the CSN1S1 gene were sequenced in 115 goats from 5 breeds (2 indigenous: Arsi-Bale and Somali, 1 exotic: Boer, and 2 crossbreeds: Boer $\times$ Arsi-Bale and Boer $\times$ Somali). The DNA analysis resulted in 35 new mutations: 3 in exons, 3 in the $5^{\prime}$ untranslated region (UTR), and 29 in the introns. The mutations in exons that resulted in an amino acid shift were then picked to evaluate their influence on individual casein content $\left(\alpha_{\mathrm{s} 1^{-}}, \alpha_{\mathrm{s} 2^{-}}, \beta-\right.$, and $\kappa-\mathrm{CN})$, micellar size, and coagulation properties in the milk from the 5 goat breeds. A mutation at nucleotide 10657 (exon 10) involved a transversion: $\mathrm{CAG} \rightarrow \mathrm{CCG}$, resulting in an amino acid exchange $\mathrm{Gln}_{77} \rightarrow \mathrm{PrO}_{77}$. This mutation was associated with the indigenous breeds only. Two new mutations, at nucleotide 6072 (exon 4) and 12165 (exon 12), revealed synonymous transitions: $\mathrm{GTC} \rightarrow \mathrm{GTT}$ in $\mathrm{Val}_{15}$ and $\mathrm{AGA} \rightarrow \mathrm{AGG}$ in $\mathrm{Arg}_{100}$ of the mature protein. Transitions $\mathrm{G} \rightarrow \mathrm{A}$ and $\mathrm{C} \rightarrow \mathrm{T}$ at nucleotides 1374 and 1866, respectively, occurred in the $5^{\prime}$ UTR, whereas the third mutation involved a transversion $\mathrm{T} \rightarrow \mathrm{G}$ at nucleotide location 1592 . The goats were grouped into homozygote new (CC), homozygote reference (AA), and heterozygote (CA) based on the nucleotide that involved the transversion. The content of $\alpha_{\mathrm{s} 1}-\mathrm{CN}(15.32 \mathrm{~g} / \mathrm{kg})$ in milk samples of goats homozygous (CC) for this newly identified mutation, $\mathrm{Gln}_{77} \rightarrow \mathrm{PrO}_{77}$ was significantly higher than in milks of heterozygous (CA; $9.05 \mathrm{~g} / \mathrm{kg}$ ) and reference (AA; 7.61 $\mathrm{g} / \mathrm{kg})$ genotype animals. The $\alpha_{\mathrm{s}^{2}}, \beta-$, and $\kappa-\mathrm{CN}$ contents showed a similar pattern. Milk from goats with a homozygous new mutation had significantly lower micellar size. Milk from both homozygote and heterozygote new-mutation goats had significantly shorter

Received December 10, 2012.

Accepted April 10, 2013.

${ }^{1}$ Corresponding author: danbebis@yahoo.com, metaas@umb.no coagulation rate and stronger gel than the reference genotype. Except the transversion, the sequence corresponded to allele $\mathrm{A}$ and presumably derived from it. Therefore, this allele is denoted by $\mathrm{A}_{3}$. All goats from the reference genotype (AA) were homozygous for the allele at nucleotide position 1374 and 1866, whereas all mutations in the $5^{\prime}$ UTR existed in a heterozygous form in both heterozygous (CA) and the new mutation (CC) genotype. The newly identified mutation (CC) detected in some of the goat breeds is, therefore, important in selection for genetic improvement and high-quality milk for the emerging goat cheese-producing industries. The finding will also benefit farmers raising these goat breeds due to the increased selling price of goats. Further studies should investigate the effect of this amino acid exchange on the secondary and tertiary structure of the $\alpha_{s 1}$-CN molecule and on the susceptibility of peptide hydrolysis by digestive enzymes.

Key words: new mutation at the $\alpha_{\mathrm{s} 1}-\mathrm{CN}$ gene, casein micelle, coagulation property, Ethiopian goat

\section{INTRODUCTION}

Milk is a complex biological fluid that contains a complete and balanced nutrient supply of proteins, carbohydrates, fats, minerals, vitamins, and other minor components essential for the growth and development of newborns and young mammals (Martin et al., 1999). Milk composition not only influences the nutritional value but also the technological properties and quality of dairy products (Yasmin et al., 2012). The composition of the goat milk varies with breed (Albenzio et al., 2006), feed (Guo et al., 2001; Morand-Fehr et al., 2007; Valenti et al., 2012), season (Talpur et al., 2008; Heck et al., 2009; O'Donnell-Megaro et al., 2011), stage of lactation (Stoop et al., 2009; Mestawet et al., 2012), and animal health (Ouweltjes et al., 2007). When it comes to the milk proteins, genetic factors are reported to predominantly determine the composition (Heck et al., 2008). Milk proteins consist of 2 major fractions: the whey proteins: $\beta-\mathrm{LG}, \alpha-\mathrm{LA}$, serum albumin $(\mathbf{S A})$, immunoglobulin, and lactoferrin $(\mathbf{L F})$, and the caseins: 
$\alpha_{\mathrm{s} 1}-\mathrm{CN}, \alpha_{s 2} \mathrm{CN}, \beta-\mathrm{CN}$, and $\kappa-\mathrm{CN}$. The 4 caseins form micelles internally bridged with calcium and phosphate by so-called micellar calcium phosphate and hydrophobic interactions (Dalgleish, 2011; de Kruif et al., 2012). Caseins appear to be very heterogeneous due to genetic polymorphism and posttranslational modifications such as phosphorylations and glycosylations. These genetic polymorphisms can affect the expression of the milk proteins in several ways. The polymorphism that occurs in the noncoding region, located within the gene's regulatory sequences, may change the level of gene expression and, hence, the amounts of RNA and protein (Fomichev et al., 2012). On the other hand, shifts in the coding sequence can lead to amino acid substitution, which may be of practical interest due to the effect they might have on protein composition and technological properties of the milk (Chiatti et al., 2007; Heck et al., 2008; Bonfatti et al., 2010).

Casein genes appear to be rapidly evolving (Prinzenberg et al., 2005), as evidenced by exceptionally high polymorphism at this locus. This has been shown to influence milk proteins and fat both qualitatively and quantitatively and has been the subject of interest and investigation for more than the last 4 decades (Ambrosoli et al., 1988; Martin et al., 2002; Ramunno et al., 2005; Chilliard et al., 2006; Park et al., 2007; Ollier et al., 2008; Küpper et al., 2010). Among the caprine casein genes, $\alpha_{\mathrm{s} 1}(\boldsymbol{C S N 1 S 1 )}$ is the most polymorphic and so far 20 alleles with 4 different quantitative expression levels (high, intermediate, low, and null) have been reported to exist (Moatsou et al., 2004; Ramunno et al., 2005; Caroli et al., 2007; Marletta et al., 2007; Küpper et al., 2010). The frequencies of these alleles vary widely among breeds (Caroli et al., 2007; Moioli et al., 2007). With this in view, many European goat breeds have been extensively investigated. The high expression level genotypes are known to predominate among the French (Pierre et al., 1999), Spanish (Jordana et al., 1996), and Italian (Sacchi et al., 2005) goat breeds, where efficient selection to increase their frequency has been performed, whereas a null variant predominates in breeds such as the Norwegian dairy goats (Hayes et al., 2006; Devold et al., 2010; Dagnachew et al., 2011). Little information exists on African breeds concerning expression of the CSN1S1 gene (Tadlaoui Ouafi et al., 2002; Caroli et al., 2007; Vacca et al., 2009), and no information exists on indigenous Ethiopian goat breeds.

In Ethiopia, several goat breeds are adapted to varying climatic conditions. A research project was initiated in 2007 with the aim of identifying suitable goat breeds for cheese production to address the increasing demand of goat milk cheese in Ethiopia. An earlier study that involved 2 indigenous Ethiopian goat breeds, a crossed breed, and one exotic breed (Mestawet et al., 2012) showed their milk had higher content of DM than many of the reported European high-yielding breeds and even higher than goat breeds at the same level of milk production. In addition, variation was shown between and within the Ethiopian goat breeds. Very high casein content and good milk-coagulation properties observed in the studied Ethiopian breeds (our unpublished data) led to investigating the genetic variants of $\alpha_{\mathrm{s} 1}$-CN. Selected regions of CSN1S1 were then genotyped, and this resulted in the detection of several new mutations. Some of the mutations assumed to have an effect on milk composition and properties were then picked for further study. This is the first time these mutations have been reported. The aim of this study was to evaluate the effect of the newly detected mutations on casein content, micellar size, and coagulation properties.

\section{MATERIALS AND METHODS}

\section{Goat Breeds and DNA Samples}

Goat breeds included in the genotyping were 2 indigenous Ethiopian goat breeds: Somali $(\mathrm{n}=32)$ and Arsi-Bale $(\mathrm{n}=35)$, the exotic Boer breed $(\mathrm{n}=32)$, and 2 crossbreeds: Boer $\times$ Arsi-Bale and Boer $\times$ Somali ( $\mathrm{n}=16$ total). All goats were stationed at Hawassa University, Ethiopia Sheep and Goat Productivity Improvement Program research station (Hawassa, Ethiopia). Boer goats were introduced in 2007 from South Africa to improve meat production. Although they are considered a meat biotype, reports also show that they are good milk producers (Greyling et al., 2004). An overview of milk yield and composition is given in Table 1. The research station practices a semi-intensive management system. Goats were grazed on natural pasture during the day for approximately $6 \mathrm{~h}$ and were given concentrate supplementation of $300 \mathrm{~g} / \mathrm{d}$ per animal in the middle of the day and green forage during confinement in the evening. Due to the objective of the project, which was producing crossbred goats, does were not milked except for the day of sampling. Kids were allowed to suckle their mothers when they were not turned out for grazing and were penned together evenings and nights until weaning, which was at 3 mo. For genotyping the goats, blood samples were collected from the jugular vein with EDTA tubes (Venoject, 0.05 mL; Terumo Europe NV, Leuven, Belgium). Genomic DNA was isolated from blood with a commercial kit (Quick-gDNA Blood MiniPrep; catalog no. D3072 and D3073; Zymo Research Corp., Irvine, CA). Polymerase chain reaction amplification and sequencing were carried out at the Centre for Integrative Genetics (CIGENE; Norwegian University of Life Sciences, Ås, Norway). Briefly, 5 primers (Table 2) covering different 
Table 1. Daily milk yield and chemical composition from different breeds

\begin{tabular}{lccrr}
\hline & \multicolumn{3}{c}{ Breed } \\
\cline { 2 - 5 } Parameter & \multicolumn{1}{c}{ Boer } & ArsiBale $^{1}$ & Somali $^{1}$ & Cross $^{2}$ \\
\hline Daily milk yield (kg/d) & $1.22^{2}$ & 1.13 & 0.85 & 1.01 \\
TS (\%) & $15.19^{2}$ & 16.27 & 14.48 & 12.84 \\
Fat (\%) & $4.64^{2}$ & 5.15 & 4.90 & 4.31 \\
Protein (\%) & $4.06^{2}$ & 4.8 & 4.34 & - \\
Lactose (\%) & $4.96^{1}$ & 4.93 & 4.97 & \\
${ }^{1}$ Mestawet et al. (2012). & & & \\
${ }^{2}$ Rekik (2012). & & &
\end{tabular}

regions of CSN1S1 were designed based on the available caprine CSN1S1 gene sequence (GenBank accession no. AJ504710.2; http://ncbi.nlm.nih.gov/genbank).

\section{DNA Amplification and Sequencing}

Three goats from each breed were sequenced using the BigDye Terminator v3.1 chemistry and ABI3730 sequencer from Applied Biosystems LLC (Foster City, $\mathrm{CA})$. Polymerase chain reactions were run in $25-\mu \mathrm{L}$ volumes and included $2.5 \mu \mathrm{L}$ of $\mathrm{MgCl}(25 \mathrm{mM}), 2.5 \mu \mathrm{L}$ of deoxyribonucleotide triphosphate (dNTP; $2 \mathrm{mM}$ ), 2.5 $\mu \mathrm{L}$ of $10 \times$ buffer $\left(\mathrm{MgCl}_{2}\right.$ free $), 1 \mu \mathrm{L}$ of forward primer $(10 \mathrm{pmol} / \mu \mathrm{L}), 1 \mu \mathrm{L}$ of reverse primer $(10 \mathrm{pmol} / \mu \mathrm{L})$, $0.15 \mu \mathrm{L}$ of Taq polymerase, and $5 \mu \mathrm{L}$ of genomic DNA $(10 \mathrm{ng} / \mu \mathrm{L})$. The PCR conditions were as follows: an initial denaturation step of $95^{\circ} \mathrm{C}$ for $10 \mathrm{~min}$, followed by 35 amplification cycles at $95^{\circ} \mathrm{C}$ for $30 \mathrm{~s}, 59^{\circ} \mathrm{C}$ for $30 \mathrm{~s}$, and $73^{\circ} \mathrm{C}$ for $90 \mathrm{~s}$, with a final extension step at $73^{\circ} \mathrm{C}$ for $10 \mathrm{~min}$. The PCR products were purified using Millipore Montage $\mathrm{PCR}_{96}$ plates (Millipore Corp., Bedford, MA).

Sequencing reactions were set up in a final volume of $10 \mu \mathrm{L}$ as follows: $1.0 \mu \mathrm{L}$ of BigDye Terminator v3.1 (Applied Biosystems LLC), $0.5 \mu \mathrm{L}$ of $5 \times$ sequencing buffer, $0.5 \mu \mathrm{L}$ of primer $(10 \mathrm{pmol} / \mu \mathrm{L})$, and $2 \mu \mathrm{L}$ of template (PCR product). The cycle sequencing reaction was carried out for 25 cycles at $96^{\circ} \mathrm{C}$ for $10 \mathrm{~s}, 50^{\circ} \mathrm{C}$ for $5 \mathrm{~s}$, and $60^{\circ} \mathrm{C}$ for $4 \mathrm{~min}$. Sequencing products were purified using a ZR-96 DNA sequencing Clean-up kit (Zymo Research Corp.) and sequenced with ABI3730 DNA analyzer (Applied Biosystems LLC). Single nucleotide polymorphisms were identified based on the Phred, Phrap, and PolyPhred programs as outlined by Nickerson et al. (1997). Contig assembly and putative SNP were visually inspected using Consed software (Gordon et al., 1998). The consensus sequence was blasted against the database of the National Center for Biotechnology Information (NCBI) Basic Local Alignment Search Tool (Aune et al., 2001), to locate the position of the sequence and SNP identified at the CSN1S1 locus. A total of 64 putative SNP were detected and used for designing primers with the online Assay Design Suite (Sequenom Inc., San Diego, CA). The 2 best multiplexes with 39 SNP, 2 of which were identified by Ramunno et al. (2005), were used to genotype 115 goats from the 5 breeds. Putative SNP were genotyped with the Sequenom MassARRAY iPLEX Gold platform (Sequenom Inc.) by use of an allele-specific matrix-assisted laser desorption/ ionization-time-of-flight (MALDI-TOF) mass spectrometry assay. Full CSN1S1 coding sequences were constructed by combining the 10 sequenced exons from the current study with the remaining 9 exons from the database (GenBank accession no. AJ504710.2; http:// www.ncbi.nlm.nih.gov/genbank). The sequences were

Table 2. Primers, size of PCR products expected, and CSN1S1 regions

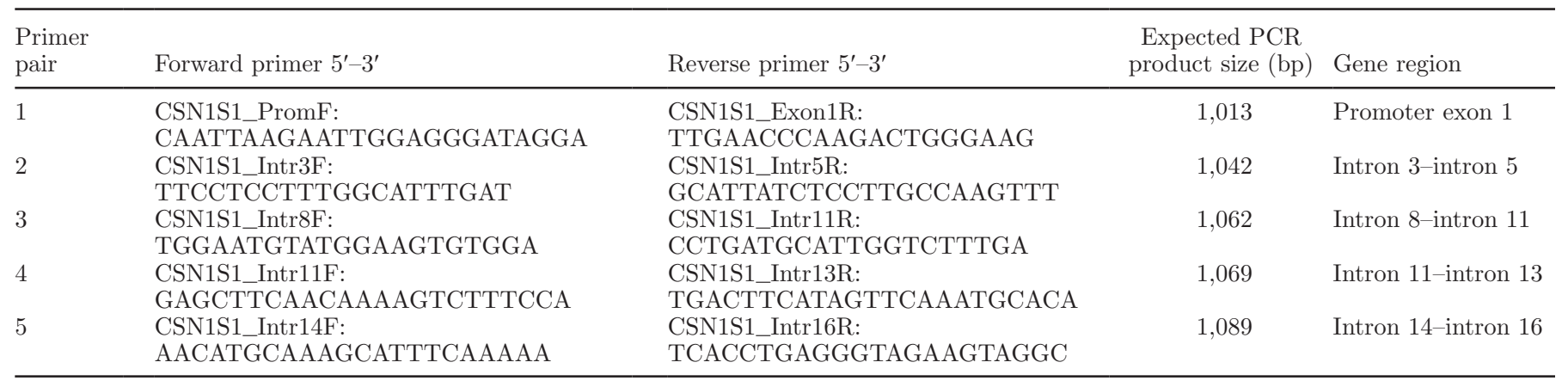


translated into amino acids at ExPASy Bioinformatics Resource Portal (http://www.expasy.org). The amino acid sequences were compared with the identified 20 genetic variants to see if any of these existed among the 5 breeds.

\section{Milk Samples and Milk Component Analysis}

To study the effect of the new mutation (at AA number 77 of the mature protein), milk samples were collected from 49 goats based on the allele types they were carrying. The genotypes were 22 homozygous reference (AA) Boer goats, 12 heterozygous (CA) goats $(7$ Boer $\times$ Arsi-Bale crosses and 5 Boer $\times$ Somali doe crosses), and 15 homozygous mutation (CC) goats (6 Arsi-Bale and 9 Somali does) at nucleotide position 10657 of the reference sequence. Milk samples (all from late-lactation stage) were kept frozen at $-20^{\circ} \mathrm{C}$ after adding 1 Bronopol tablet per $40 \mathrm{~mL}$ of milk (2-bromo-2-nitropane-1,3-diol; D \& F Control Systems Inc., Norwood, MA) until they were brought to the Norwegian University of Life Sciences for analysis. Milk DM content was determined by a direct forced-air oven drying method (IDF-ISO-AOAC, 2005). Crude protein content was determined by the Kjeldahl method (ISO and IDF, 2001) using a Kjeltec 8400 Analyzer, (Foss Analytical AB, Höganäs, Sweden). Samples were run in triplicate.

\section{Quantification of Individual Caseins by Capillary Electrophoresis}

Preparation of Buffers and Samples for Capillary Electrophoresis Analysis. Milk sample and run buffers were prepared according to Ribeiro et al. (2000) and Heck et al. (2008). Varying concentrations of individual goat caseins: $\alpha_{\mathrm{s}^{-}}, \alpha_{\mathrm{s} 2^{-}}, \beta-$, and $\kappa-\mathrm{CN}$ were used to determine the elution order and estimate the concentration in milk samples. Along with this, $\beta-\mathrm{CN}$ standard from cow milk was used for quantification. Individual casein standards, which were purified from goat milk according to Criscione et al. (2011), were dissolved with a known concentration in a sample buffer. Whole milk samples $(600 \mu \mathrm{L})$ were mixed with sample buffer $(900 \mu \mathrm{L})$, briefly vortexed, and left at room temperature for an hour and centrifuged at 5,000 RCF for 5 min. All samples were then kept in a refrigerator $\left(4^{\circ} \mathrm{C}\right)$ for about $10 \mathrm{~min}$ to ease removal of the fat. Both the run buffer and the samples were filtered through 0.45$\mu \mathrm{m}$ filter unit (Millipore Corp.).

Milk and Standard Sample Analysis with Capillary Electrophoresis. Analysis of milk and casein standard samples was carried out on an Agilent capillary electrophoresis system (Agilent Technologies
Deutschland GmbH, Waldbronn, Germany) controlled by Agilent ChemStation software based on the method of Heck et al. (2008). The ChemStation software was also used for data acquisition and data analysis. Separations were performed using a fused silica deactivated capillary with dimensions of $56 \mathrm{~cm} \times 50-\mu \mathrm{m}$ i.d. and a slit opening of $100 \times 800 \mu \mathrm{m}$. Separations were carried out in a positive polarity at $45^{\circ} \mathrm{C}$ with a linear voltage gradient from 0 to $25 \mathrm{kV}$ in $3 \mathrm{~min}$, followed by a constant voltage of $25 \mathrm{kV}$ for $45 \mathrm{~min}$ with $20 \mathrm{~m} M$ sodium acetate buffer at $\mathrm{pH}(3 \pm 0.1)$. A calibration curve was fitted for each casein from varying concentrations designed to encompass the lower and higher expected concentration level for each of the caseins in milk. All samples were run in a sequence. Each sequence comprised 6 milk samples and 1 standard sample of known concentration. Before each run, the capillary was flushed with run buffer for 5 min. At the beginning, and after every 4 runs, a method that involved flushing the capillary with $1 \mathrm{~N}$ $\mathrm{NaOH}$ for 5 min followed by flushing with run buffer for 20 min was developed to condition the capillary. As the electrolysis of a solution can alter the running buffer $\mathrm{pH}$ and the migration of ions between anode and cathode, fresh sample buffer was used after every 3 runs. Sample solutions were injected at a pressure of $3.447 \mathrm{~Pa}$ for 20 $\mathrm{s}$ at the anode. Caseins were detected by a UV detector set at $214 \mathrm{~nm}$. Each peak was identified by comparing its retention time to an electropherogram of caprine casein standards. The concentration of the different caseins in the milk samples were determined using the equation from the calibration curve fitted to each casein standard. Two strong and 2 null $\alpha_{\mathrm{s} 1}-\mathrm{CN}$ goat milk samples provided by Institut National de la Recherche Agronomique (INRA; Jouy-en-Josas, France) were run for comparison. Samples were run in triplicate.

\section{Casein Micellar Size}

The size of native micelles in milk was measured by photon correlation spectroscopy as described by Devold et al. (2000) using a Zetasizer 3000HS instrument (Malvern Instruments Ltd., Malvern, UK). Milk samples for micellar size determination were prepared as follows: 5 $\mu \mathrm{L}$ of skim milk sample was diluted in $4 \mathrm{~mL}$ of simulated milk ultrafiltrate (SMUF; Jenness and Koops, 1962) filtered through a $0.22-\mu \mathrm{m}$ filter (Millipore Corp.). The diluted samples were then filtered through a $0.8-\mu \mathrm{m}$ filter and the temperature was brought to $25^{\circ} \mathrm{C}$ before measurement. Samples were run in triplicate.

\section{Milk Coagulation Properties}

Rennet clotting time [the time (in min) from addition of rennet to the starting point of curd formation], curd- 
firming rate [the time (in min) from the starting point of curd formation until the curve width of $20 \mathrm{~mm}$ ], and curd firmness or gel strength [the width (in $\mathrm{mm}$ ) of the curve 30 min after renneting] were measured by a Lattodinamografo (Foss-Italia S.p.A., Padova, Italy). Before addition of rennet [chymosin, 200 international milk clotting units (IMCU)/mL; Naturen Standard 190; Chr. Hansen Laboratorium, Hørsholm, Denmark], the temperature of the milk sample was brought to $30^{\circ} \mathrm{C}$ in a heated block. Chymosin was diluted in sodium acetate buffer (1.71 M sodium chloride, $0.073 \mathrm{M}$ sodium acetate trihydrate and $0.0035 \mathrm{M}$ acetic acid, $\mathrm{pH}$ 5.6) in a ratio of 1:50. For each $10 \mathrm{~mL}$ of heated milk sample, $200 \mu \mathrm{L}$ of diluted enzyme was added, mixed for about $5 \mathrm{~s}$ before determination of the coagulation properties. All samples were run in triplicate.

\section{Statistical Analysis}

The dependent variables $(y)$ were analyzed using the mixed model procedure (PROC MIXED) of SAS (release 9.1; SAS Institute Inc., Cary, NC), according to the following model:

$$
y=\mu+\text { breed }+ \text { genotype }+ \text { goat }+ \text { residual, }
$$

where $\mu=$ population mean. The fixed effect included 5 breeds (Arsi-Bale, Somali, Boer, and 2 crossbreeds) and 3 genotypes [homozygous mutation (CC), homozygous reference (AA), and heterozygote (CA)]. The random effects were goat and residual. Differences between treatment means were considered significant when resultant $P$-values were $<0.05$ for the $F$-test in the ANOVA. Principal components analysis and correlations were performed by XLSTAT software (version 2012.5.02; Addinsoft, Paris, France) on data for milk TS, protein individual casein amount, and micellar size for the 3 genotypes and 5 goat breeds.

\section{RESULTS AND DISCUSSION}

\section{Description of New Mutations in the Selected Ethiopian Goat Population}

Selected regions of $C S N 1 S 1$ were sequenced. This allowed detection of several new SNP: 3 in the $5^{\prime}$ untranslated region (UTR), 3 in exons (exons 4, 10, and 12), and 29 in the intronic region. The $3 \mathrm{SNP}$ in the exon regions that occurred at amino acid 15, 77, and 100 of the mature protein along with the 3 SNP from the $5^{\prime}$ UTR are considered in this paper. The first mutation revealed a synonymous transition GTC $\rightarrow$ GTT in the $\mathrm{Val}_{15}$ of the mature protein. The transition occurred in nucleotide 6072 (exon 4) of the reference CSN1S1 se- quence (GenBank accession no, AJ504710.2; Ramunno et al., 2004). To our best knowledge, mutation at this position has never been reported before.

The second mutation involved a transversion $\mathrm{CAG} \rightarrow$ CCG resulting in an amino acid exchange $\mathrm{Gln}_{77} \rightarrow \mathrm{PrO}_{77}$ in the mature protein. The transversion occurred in nucleotide 10657 (exon 10) of the reference CSN1S1 sequence (GenBank accession no. AJ504710.2). Three independent studies in different goat breeds have reported nonsynonymous mutation, all of which involved exchange of $\mathrm{Glu}_{77} \rightarrow \mathrm{Gln}_{77}$ (Brignon et al., 1989; Martin and Leroux, 1994; Chianese et al., 1997). The mutation observed in the current study was detected in the indigenous Ethiopian goats and their crosses with the Boer goats. A mutation that resulted in a shift to proline $\left(\mathrm{Leu}_{16} \rightarrow \mathrm{Pro}_{16}\right)$ has been reported in $\mathrm{B} 2, \mathrm{~B} 4, \mathrm{C}$, $\mathrm{D}, \mathrm{E}, \mathrm{F}$, and $\mathrm{L}$ genetic variants of $\alpha_{\mathrm{s} 1}{ }^{-} \mathrm{CN}$ (Marletta et al., 2007). In other species, the change of $\mathrm{His}_{67}$ to $\mathrm{Pro}_{67}$ in bovine $\beta-\mathrm{CN}$ A1 was reported to inhibit cleavage at this particular position by pepsin, trypsin, or chymotrypsin (De Noni, 2008) during digestion. It has been hypothesized that the resulting bioactive peptide ( $\beta$-casomorphin- 7$)$ may be associated with the development of type 1 diabetes in genetically susceptible subjects (Merriman, 2009).

In an effort to see the response of the peptide chain to hydrolysis, the amino acid sequence with mutated proline was tested in the PeptideCutter program at ExPASy Bioinformatics Resource Portal (http://web. expasy.org). The test showed that the presence of proline at this particular position inhibited pepsin ( $\mathrm{pH} 1.3)$ hydrolysis of the adjacent amino acid lysine. Several other notable effects can exist due to this shift. The first one is a change in physical property. Proline is a hydrophobic amino acid with hydrophobicity of -0.2 , whereas glutamine has a hydrophobicity of -4.1 (Branden and Tooze, 1999). The other notable expected effect could be a change in protein flexibility. Proline is a very rigid amino acid known to disrupt $\alpha$-helixes, whereas glutamine is not. To shed light on the putative structural consequences of the $\mathrm{Gln}_{77}$ to $\mathrm{Pro}_{77} \mathrm{mu}-$ tation observed in $\alpha_{\mathrm{s} 1} \mathrm{CN}$, an attempt was made to assign secondary structure properties to the sequence. Because no homolog to $\alpha_{\mathrm{s} 1}$-CN with known structure exists, secondary structure of the protein was predicted by Psipred (Buchan et al., 2010) and Jpred3 (Cole et al., 2008). However, the results were inconclusive and no consensus was found, providing no clear answer to the putative structural consequence of this mutation. Proline is also known to increase molecule stability and resistance to heat (Branden and Tooze, 1999). Even if each mutation may cause a small change in stability of the protein molecule, the occurrence of several of such mutations should have a significant effect. In all 
cases, insufficient information exists to conclude that the shift can either result in the generation of a bioactive peptide or affect hydrolysis and protein structure in any way. However, we can only speculate that this mutation is drastic and is likely to have an effect on the chemical and physical properties of the mature protein (Ceriotti et al., 2004), which might ultimately affect milk technological properties (Martin et al., 2002; Heck et al., 2008).

A synonymous transition, $\mathrm{AGA} \rightarrow \mathrm{AGG}$, in the amino acid $\operatorname{Arg}_{100}$ in the mature protein was the third mutation that was detected, in nucleotide 12465 (exon 12) of the reference sequence (GenBank accession no. AJ504710.2). Three previously reported independent findings show a shift from $\operatorname{Arg}_{100} \rightarrow \mathrm{Lys}_{100}$ at this position (Boulanger et al., 1984; Grosclaude et al., 1987; Brignon et al., 1989). The SNP detected in this study, however, has never been reported before.

The SNP in the 5' UTR included a transition mutation $\mathrm{G} \rightarrow \mathrm{A}$ at nucleotide position 1374, a transversion mutation $\mathrm{T} \rightarrow \mathrm{G}$ at nucleotide location 1592, and a transition mutation $\mathrm{C} \rightarrow \mathrm{T}$ at nucleotide location of 1866 of the reference CSN1S1 sequence (GenBank accession no. AJ504710.2; Ramunno et al., 2004). Linkage disequilibrium (LD) was tested to see associations between the 6 SNP. Only SNP $1(\mathrm{G} \rightarrow \mathrm{A}$ at nucleotide 1374$)$ showed high $\mathrm{LD}$, whereas the others showed no LD to very low LD (results not presented). None of the SNP responsible for null genotype of $\alpha_{\mathrm{s} 1}-\mathrm{CN}$, which are reported to exist in some West African goats (Caroli et al., 2007), a few among the Tunisian goat population (Vacca et al., 2009), and in some European breeds (Marletta et al., 2005; Sacchi et al., 2005; Moatsou et al., 2008) were detected in the current study. In general, as the few studies conducted on other African goat breeds indicate, alleles associated with higher expression seem to predominate the indigenous Ethiopian goat population studied.

\section{Quantification of Individual Caseins in Different Genotype Milk Samples by CE}

Milk protein fractions were eluted in the following order: $\alpha$-LA and then small peaks of $\alpha_{\mathrm{s} 2}-\mathrm{CN}, \beta-\mathrm{LG}$, $\alpha_{\mathrm{s} 2^{-}} \mathrm{CN}, \alpha_{\mathrm{s} 1^{-}} \mathrm{CN}, \kappa-\mathrm{CN}$, and $\beta$-CN (Figure 1). Except for the small peak of $\alpha_{\mathrm{s} 2}-\mathrm{CN}$ that appeared between $\alpha$-LA and $\beta-\mathrm{LG}$, the order is in agreement with other studies (Gómez-Ruiz et al., 2004; Heck et al., 2008; Valenti et al., 2012). The electropherograms in Figure 1 represent the homozygous form of the new mutation (CC), reference allele (AA), heterozygote (CA), and another 2 samples: strong and null variants of $\alpha_{s 1}$ - $\mathrm{CN}$ from French goats. Variations in elution time were observed with longer use of the capillary. In all genotypes, $\alpha_{s 1}-\mathrm{CN}$ separated into multiple peaks with variable size and shape as has been observed from other reports (Clark and Sherbon, 2000; Heck et al., 2008; Valenti et al., 2012). The new homozygote genotype (CC) separated in 3 relatively higher peaks for $\alpha_{\mathrm{s} 1} \mathrm{CN}$ (high mAU) with a shoulder on the second peak (Figure 1A). In local reference genotype goats (Figure 1B), it was common to observe 3 major peaks (relatively shorter than for the homozygote new genotype), with a shoulder on the second peak, whereas in the exotic goats (Figure 1C), electropherograms with 2 major peaks, each having a distinct shoulder, dominated. The heterozygote individuals (cross between A and C) had 3 peaks, with shoulders on the second and third peaks. They apparently have inherited the characteristics of both parents (Figure 1D). In the French reference samples, the strong $\alpha_{s 1}$ CN peaks did not have any shoulder (Figure $1 \mathrm{E}$ ), whereas no peak was observed for $\alpha_{\mathrm{s} 1} \mathrm{CN}$ in the French null genotype (Figure $1 \mathrm{~F}$ ). In a study by Clark and Sherbon (2000), a null genetic variant did not have a peak at the position of $\alpha_{\mathrm{s} 1}-\mathrm{CN}$. All goats and genotypes in this study had peaks at the $\alpha_{\mathrm{s} 1}-\mathrm{CN}$ position and so we observed no null genetic variant of $\alpha_{\mathrm{s} 1}$-CN in the studied goat population.

The content of $\alpha_{\mathrm{s} 1}-\mathrm{CN}(15.32 \mathrm{~g} / \mathrm{kg})$ in the homozygous new-mutation (CC) milk samples was significantly higher $(P<0.001)$ than in the heterozygotes $(9.05 \mathrm{~g} /$ $\mathrm{kg}$ ) and the reference $(7.61 \mathrm{~g} / \mathrm{kg}$ ) milk type (Table $3)$. The difference between the heterozygotes and the reference genotype, however, was not significant $(P>$ 0.05). The content of $\alpha_{\mathrm{s} 1} \mathrm{CN}$ found in this study for the homozygote was higher than reported results for the strong genotypes BB (7.44 to $12.32 \mathrm{~g} / \mathrm{kg}$ ) but was comparable to the heterozygote and reference genotype (Gómez-Ruiz et al., 2004). Higher contents of $\alpha_{\mathrm{s} 1}$-CN are associated with the strong genetic variants, which are reported to have approximately 3.5 to $4.2 \mathrm{~g} / \mathrm{L}$ per allele of $\alpha_{s_{1}-}$ CN (Marletta et al., 2007; Moatsou et al., 2008; Küpper et al., 2010). The contents of $\alpha_{\mathrm{s} 1^{-}}$ CN obtained in this study, in particular for the new mutation and heterozygous goat milk are higher than most of the results reported for the strong genotype so far (Grosclaude et al., 1987; Martin et al., 1999; Clark and Sherbon, 2000; Marletta et al., 2007; Moatsou et al., 2008). From the content of $\alpha_{s 1}$-CN obtained in this study, we can clearly see that the new mutation did not result in any of the intermediate $(\sim 1.1$ to $1.6 \mathrm{~g} / \mathrm{L}$ per allele of $\left.\alpha_{\mathrm{s} 1}-\mathrm{CN}\right)$, weak $(\sim 0.45$ to $0.6 \mathrm{~g} / \mathrm{L}$ per allele of $\alpha_{\mathrm{s} 1} \mathrm{CN}$ ) or null (apparent absence of $\alpha_{\mathrm{s} 1}-\mathrm{CN}$ ) genotypes; rather, it looks to be associated with the higher synthesis of $\alpha_{\mathrm{s} 1}-\mathrm{CN}$. A point to note here is that the milk samples were drawn from the late-lactation stage and this must have contributed to the higher milk content, too. However, compared with the $\alpha_{\mathrm{s} 1}$-CN level obtained 


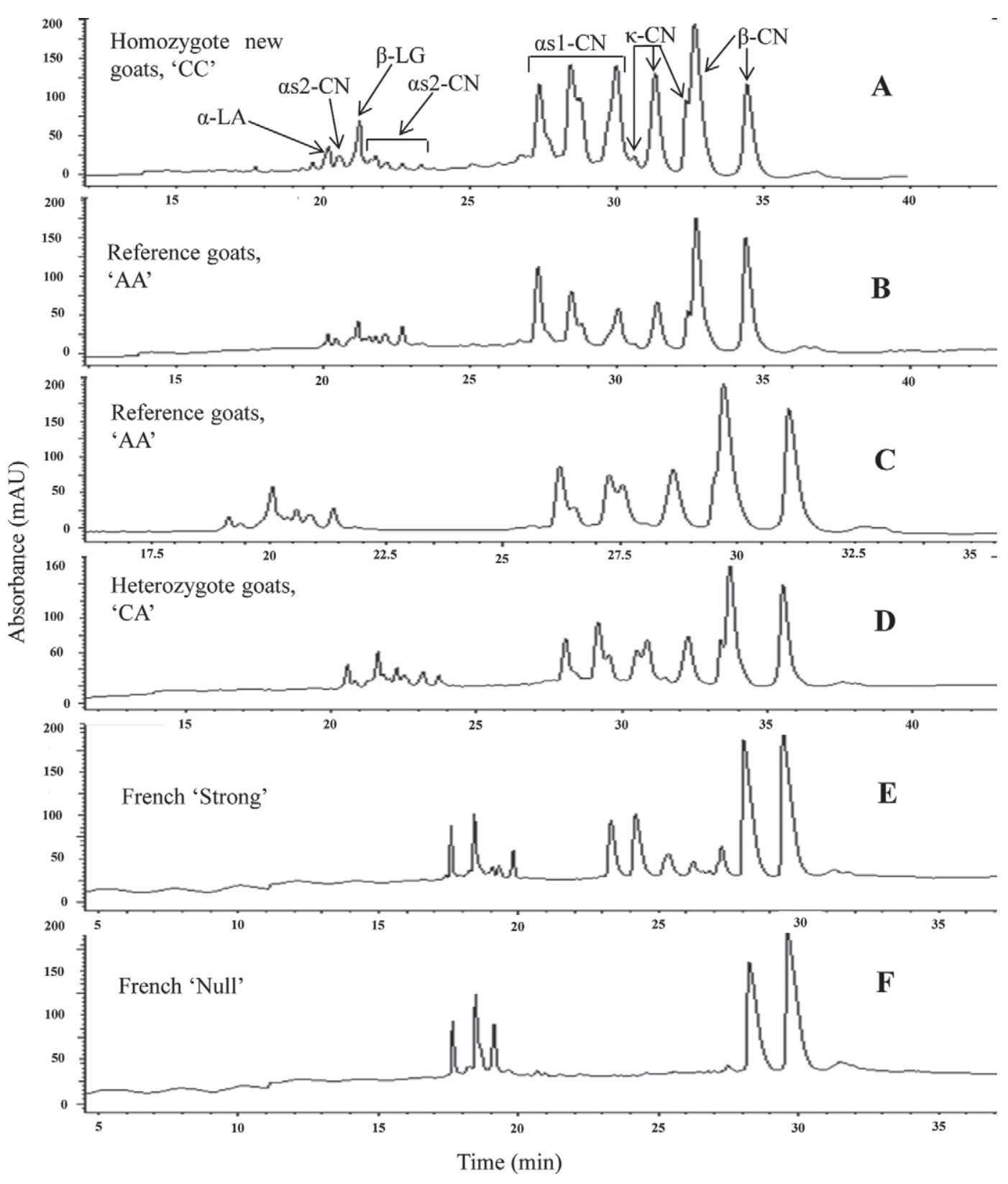

Figure 1. Sample electropherograms of milk protein from different goats with varying genotypes. A $=$ homozygous new mutation; $\mathrm{B}=$ reference genotype of indigenous goat; $\mathrm{C}=$ reference genotype of exotic goat; $\mathrm{D}=$ heterozygous genotype (a cross between Boer and Arsi-Bale or Boer and Somali); $\mathrm{E}=$ French strong $\alpha_{\mathrm{s} 1}$ genotype; $\mathrm{F}=$ French null $\alpha_{\mathrm{s} 1} \mathrm{CN}$.

in a previous study from the same goat breeds at the late-lactation stage, the amount obtained in the current study is high (T. A. Mestawet, unpublished data). The new mutation thus can be classified as a strong genetic variant of $\alpha_{\mathrm{s} 1}$-CN. Allele $C S N 1 S 1^{*} A$ was used as a reference sequence, although $\mathrm{N}$ and $\mathrm{F}$ alleles were checked as well. Except the transversion, the sequence corresponded to allele A and presumably derived from it. Therefore, this allele is denoted by $\mathrm{A}_{3}$. The rest of the caseins $\left(\alpha_{\mathrm{s} 2^{-}}, \kappa^{-}\right.$, and $\left.\beta-\mathrm{CN}\right)$ followed a similar pattern, being higher in the milk of animals homozygous for the new allele than in heterozygotes and the reference goat milk $(P<0.05)$. It is also worth noting that, except for the differences observed between the different groups, the content obtained was high or comparable with the strong $\alpha_{\mathrm{s} 1} \mathrm{CN}$ so far reported. The very high DM content of milk in homozygous and heterozygous groups (Table 4) was also due to the stage of lactation (late lactation) at which milk samples were collected and the inherent low milk yield that is usually associ- 
ated with high milk component concentrations (Table 1). Stage of lactation is known to significantly influence milk composition, with the late-lactation stage usually having higher concentrations of milk components (Guo et al., 2001; Soryal et al., 2005; Mestawet et al., 2012).

A notable difference was also observed in the SNP detected at the $5^{\prime}$ UTR between the different genotypes. All goats from the reference genotype (AA) were homozygous for the mutation at nucleotide position 1374 and 1866, whereas all of the 3 mutations in the $5^{\prime}$ UTR existed mainly in a heterozygous form in both heterozygous (CA) and the new mutation (CC) genotypes. Mutations in the $5^{\prime}$ UTR are known to affect protein expression (Branden and Tooze, 1999; Fomichev et al., 2012), which needs further investigation.

\section{Mean Casein Micellar Size as Influenced by the New Mutation}

The casein micellar size in milk from the homozygous new-mutation goats $(187.25 \mathrm{~nm})$ was significantly smaller $(P<0.001)$ than both reference and the heterozygous groups (Table 3 ). The mean micellar size obtained for the homozygous new mutation was comparable with the result reported for a French strong genetic variant (199 nm; Pierre et al., 1995). However, it was smaller than that reported by Martin et al. (1999) for the same genetic variant of $\alpha_{\mathrm{s} 1}$-CN, in a different goat breed (221 $\mathrm{nm})$. All milk samples showed narrow ranges of distribution. Overall, the range for the 3 genotypes agreed with what has been reported for the stronger genetic variants of $\alpha_{\mathrm{s} 1}-\mathrm{CN}$, although there are some contradicting reports. In a study by Pierre et al. (1999), a narrow range was reported to be associated with the strong variant (A-milk), whereas Tziboula and Horne (1999) reported the contrary. What can be generalized from the various reports is that the lower mean sizes and narrower ranges are always associated with the strong genetic variants of $\alpha_{\mathrm{s} 1}$-CN. Smaller micellar sizes are known to form a more compact casein network, thereby entrapping fat within the network and thus forming firmer gels, which gives milk the desirable technological property (O'Connell and Fox, 2000; Glantz et al., 2010).

\section{Coagulation Properties of Milk from the Different Genotypes}

The coagulation properties observed in different milk groups are desirable technological properties (Table 4 and Figure 2). The rennet clotting time did not vary significantly $(P>0.05)$ between the different genotypes and is comparable with previously reported for goats with a strong genotype of $\alpha_{\mathrm{s} 1}-\mathrm{CN}$ (Clark and Sherbon,

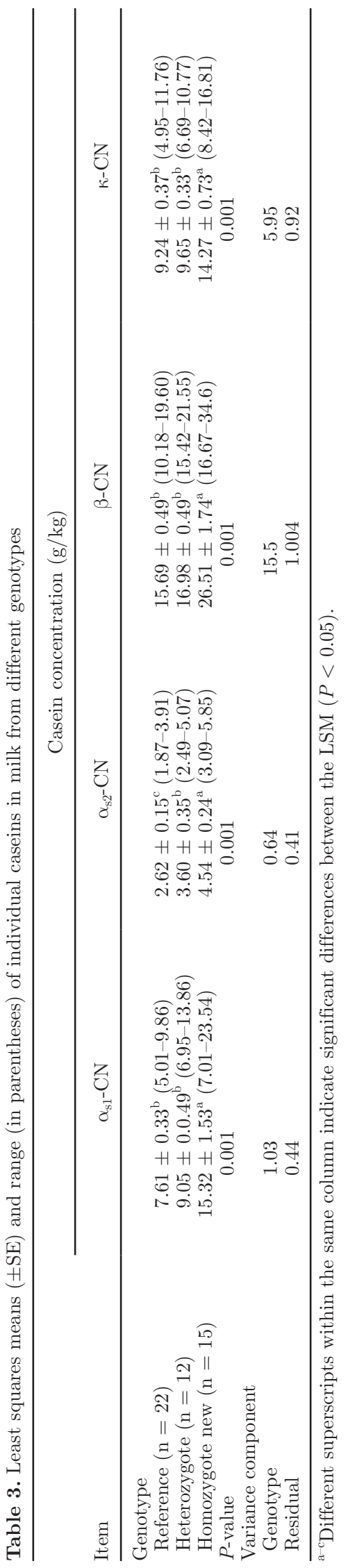


Table 4. Least squares means ( $\pm \mathrm{SE}$ ) and range (in parentheses) of DM, CP, coagulation properties, and micellar size of milk from different genotypes

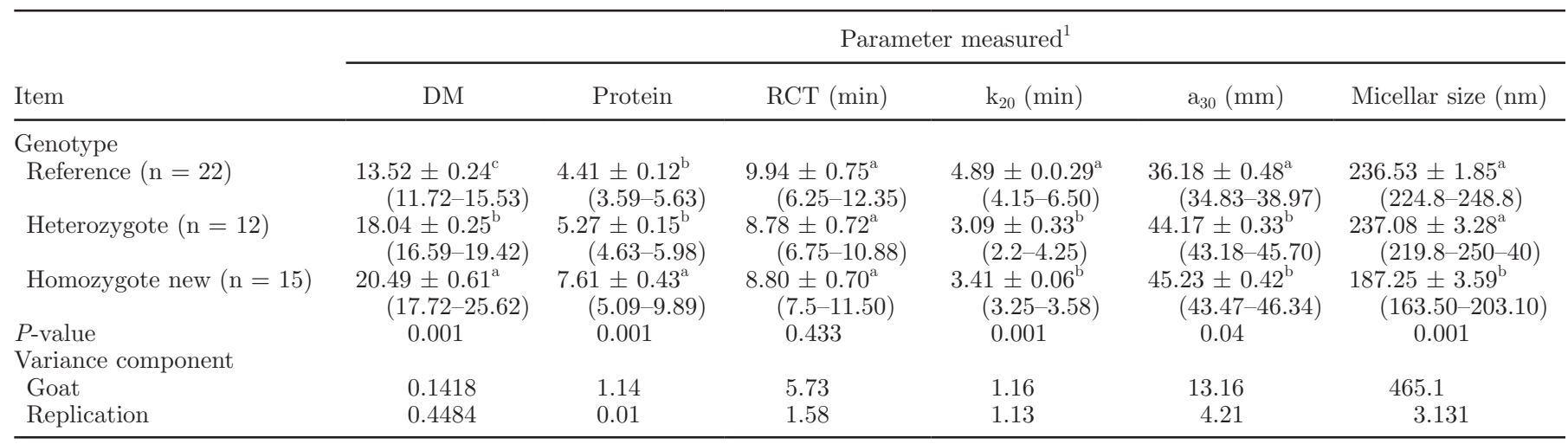

${ }^{\mathrm{a}-\mathrm{c}}$ Different superscripts within the same column indicate significant differences between the LSM $(P<0.05)$.

${ }^{1} \mathrm{RCT}=$ rennet clotting time; $\mathrm{k}_{20}=$ curd-firming rate; $\mathrm{a}_{30}=$ gel strength (or curd firmness).

2000). Milk samples from homozygous new-mutation (CC) animals and heterozygotes (CA) attained the curd-firming rate in 3.41 and 3.09 min, respectively, a significantly shorter time $(P<0.001)$ than that taken to attain the same gel strength by the reference (AA) genotype $(4.89 \mathrm{~min})$. The time taken by the 3 genotypes to attain the 20 -mm gel strength was, however, shorter than that taken to attain the same gel strength in the strong genotype of $\alpha_{s_{1}}$ CN milk in a Norwegian dairy goat population (11.2 min; Devold et al., 2010). The rate of curd firming for all groups in the current study,

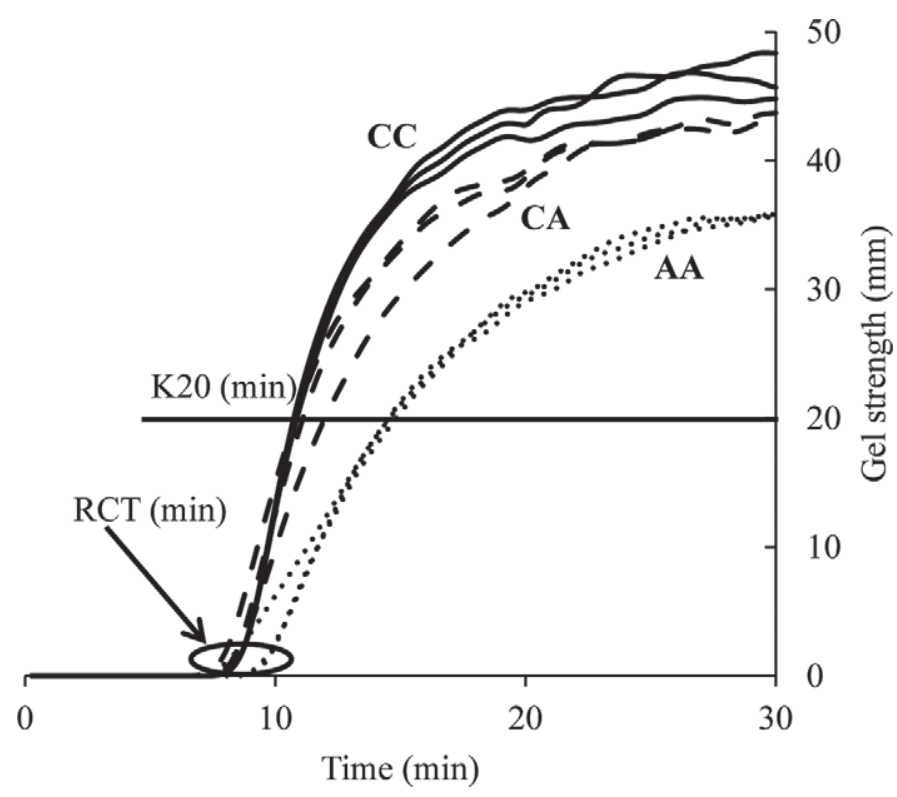

Figure 2. Coagulation properties of milk from the 3 milk groups as a function of time during curd formation. $\mathrm{CC}=$ homozygous mutation; $\mathrm{CA}=$ heterozygous mutation; $\mathrm{AA}=$ reference genotype; $\mathrm{RCT}=$ rennet clotting time; $\mathrm{k}_{20}=$ curd-firming rate. however, falls in the range given for the strong genotype of $\alpha_{\mathrm{s} 1}-\mathrm{CN}$ (Clark and Sherbon, 2000; Guo et al., 2001).

The curd was significantly firmer $(P<0.05)$ in the homozygous new-mutation $(45.23 \mathrm{~mm})$ and heterozygote milk samples $(44.17 \mathrm{~mm})$ than in the reference milk sample $(36.18 \mathrm{~mm})$. The gel strength obtained for the reference genotype was comparable with that reported for Alpine goats $(37.16 \mathrm{~mm})$ carrying the strong genotype of $\alpha_{\mathrm{s} 1}$-CN (Ambrosoli et al., 1988). The gel strength for the new mutation and heterozygous group in the current study was exceptionally high compared with results reported for the strong genotypes (Ambrosoli et al., 1988; Zullo et al., 2005; Devold et al., 2010) and to our knowledge, no gel strength comparable to that found for both groups has been reported before. The higher TS content of the milk, which is also expected to have high fat content and smaller micellar size, all favor formation of firmer gels (Sevi et al., 2000; Thomann et al., 2008) and are reasons for the good coagulation properties observed.

\section{Principal Component Analysis and Association Between New Mutation and Selected Milk Components}

Biplots of principal component analysis (observations and variables) carried out on 3 groups of milk (homozygote, heterozygote, and reference) and milk characteristics are presented in Figure 3. An overview of breeds and milk characteristics within the genotype used in plotting are given in Appendix Table A1. The first 2 principal components explained most of the variation (83.99\%), with the first principal component accounting for $74.37 \%$ of the total variation. Milk components increased along the principal component 1 . The reference group (group 1) clustered in the negative part of the principal component 1, indicating a lower content of 


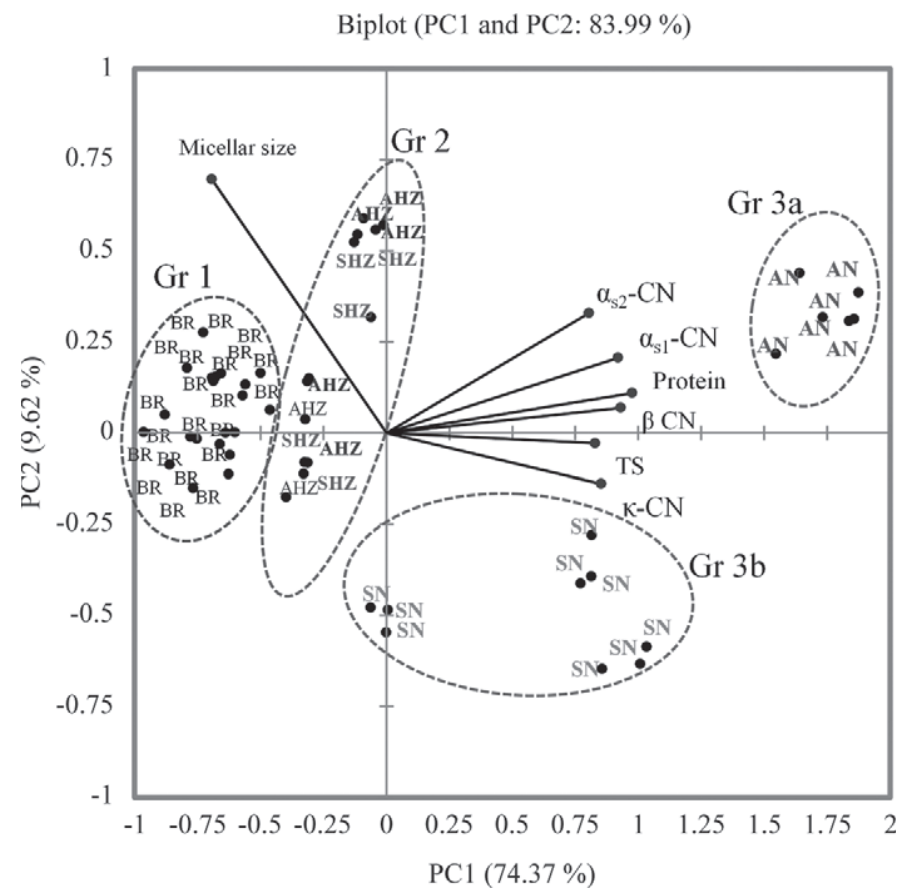

Figure 3. Principal components (PC) analysis plot of different genotypes, caseins, micellar size, proteins, and TS. $\mathrm{Gr}=$ group; $\mathrm{BR}=$ Boer reference genotype; $\mathrm{AN}=$ Arsi-Bale new mutation; $\mathrm{SN}=$ Somal new mutation; ANZ $=$ Boer $\times$ Arsi-Bale cross heterozygote; $\mathrm{SHZ}=$ Boer $\times$ Somali cross heterozygote.

milk components. The homozygote new mutation that grouped further based on breed: group 3a (Arsi-Bale) and group 3b (Somali) were best explained by higher milk component concentrations: TS protein and the 4 caseins. Group 2 comprised the heterozygous genotype (CA), which is the cross between group 1 (reference genotype) and groups $3 \mathrm{a}$ and $3 \mathrm{~b}$. The characteristic of this group is much similar to that of group 1 . The inherent breed differences in milk content between groups $3 \mathrm{a}$ and $3 \mathrm{~b}$ witnessed in a previous study (Mestawet et al., 2012) could be the reason for them not to cluster together as group 1. Micellar size separated and increased along principal component 2 (9.62\%). The homozygote new mutation groups were located in the lower negative part of principal component 2 (group $3 \mathrm{~b})$ and the positive side of principal component 1 (group 3b), indicating their stronger association with smaller micelles than group 1 and group 2. The other notable trend was that the micellar size was negatively correlated with all milk components. The association observed between the milk components is in agreement with results from different scholars (Pierre et al., 1999; Clark and Sherbon, 2000)

\section{CONCLUSIONS}

A total of 35 new mutations, 3 in the $5^{\prime}$ UTR, 3 in the exon, and 29 in the intron regions of the CSN1S1 gene, were detected. One of the new mutations that involved the shift of amino acid $\mathrm{Gln}_{77} \rightarrow \mathrm{PrO}_{77}$ is a drastic shift and is of particular interest due to the effect it may have in the protein molecule, including structural effect, physical property effect, and digestion and formation of a different peptide pattern. Future studies could address these issues with additional work on nutritional properties. This mutation was shown to positively influence $\alpha_{\mathrm{s} 1} \mathrm{CN}$ content and coagulation. From these properties, it is possible to categorize the new mutation among the strong genotype of $\alpha_{\mathrm{s} 1}$-CN and it is denoted $\mathrm{A}_{3}$. The 3 mutations in the $5^{\prime} \mathrm{UTR}$, 2 of which were detected in homozygous form in the exotic reference genotype, suggest that they might have a role in the level of gene expression. This study is of high significance both for future breeding, for the scientific community in general, and for the emerging goat cheese industry at the local level. Besides providing some interesting new results, this study has also opened many areas that need to be investigated further to understand the nature of the new mutation both at exon 10 that involved amino acid 77 and the 3 new SNP in the $5^{\prime}$ UTR.

\section{ACKNOWLEDGMENTS}

The present work was supported by the Norwegian University of Life Sciences (Ås, Norway), United Nations Educational, Scientific and Cultural Organization (UNESCO)-L'Oréal (Paris, France), and Hawassa University (Hawassa, Ethiopia). We are grateful to K. K. Sundsaasen, M. P. Kent, and S. Lien of the Centre for Integrative Genetics (CIGENE; Norwegian University of Life Sciences) for their work on genotyping the goats. We extend our thanks to Patrice Martin (INRA, France) who kindly provided us milk samples from the strong and null variants of $\alpha_{\mathrm{s} 1}-\mathrm{CN}$. The valuable assistance of Gustav Vaaje-Kolstad (Norwegian University of Life Sciences) in protein structure determination is also acknowledged. The authors are grateful to Bekele, Dubale, Hossie, Dawit, Wondwesen, and Abinet (all from Hawassa University, Hawassa, Ethiopia) who were involved in one way or another in field work related to the experimental goats and blood collection. We extend our thanks to the Department of Biotechnology (Addis Ababa University, Addis Ababa, Ethiopia) for allowing us to use their laboratory and their facility during DNA extraction.

\section{REFERENCES}

Albenzio, M., M. Caroprese, R. Marino, A. Muscio, A. Santillo, and A. Sevi. 2006. Characteristics of Garganica goat milk and Cacioricotta cheese. Small Rumin. Res. 64:35-44. 
Ambrosoli, R., L. di Stasio, and P. Mazzocco. 1988. Content of $\alpha_{\mathrm{s} 1^{-}}$ casein and coagulation properties in goat milk. J. Dairy Sci. $71: 24-28$.

Aune, J. B., M. T. Bussa, F. G. Asfaw, and A. A. Ayele. 2001. The ox ploughing system in Ethiopia: Can it be sustained? Outlook Agric. 30:275-280.

Bonfatti, V., G. Di Martino, A. Cecchinato, D. Vicario, and P. Carnier. 2010. Effects of $\beta$ - $\kappa$-casein (CSN2-CSN3) haplotypes and $\beta$-lactoglobulin (BLG) genotypes on milk production traits and detailed protein composition of individual milk of Simmental cows. J. Dairy Sci. 93:3797-3808.

Boulanger, A., F. Grosclaude, and M.-F. Mahé. 1984. Polymorphisme des caséines $\alpha_{\mathrm{s} 1}$ et $\alpha_{\mathrm{s} 2}$ de la chévre (Capra hircus). Genet. Sel. Evol. 16:157-176.

Branden, C., and J. Tooze. 1999. Introduction to Protein Structure. 2nd ed. Garland Publishing Inc., New York, NY.

Brignon, G., M. Mahé, F. Grosclaude, and B. Ribadeau-Dumas. 1989. Sequence of caprine $\alpha_{\mathrm{s} 1}$-casein and characterization of those of its genetic variants which are synthesized at a high level, $\alpha_{\mathrm{s} 1}-\mathrm{CnA}, \mathrm{B}$ and C. Protein Seq. Data Anal. 2:181-188.

Buchan, D. W., S. M. Ward, A. E. Lobley, T. C. Nugent, K. Bryson, and D. T. Jones. 2010. Protein annotation and modelling servers at University College London. Nucleic Acids Res. 38(Web Server issue):W563-W568.

Caroli, A., F. Chiatti, S. Chessa, D. Rignanese, E. M. Ibeagha-Awemu, and G. Erhardt. 2007. Characterization of the casein gene complex in West African goats and description of a new $\alpha_{\mathrm{s} 1}$-casein polymorphism. J. Dairy Sci. 90:2989-2996.

Ceriotti, G., S. Chessa, P. Bolla, E. Budelli, L. Bianchi, E. Duranti, and A. Caroli. 2004. Single nucleotide polymorphisms in the ovine casein genes detected by polymerase chain reaction-single strand conformation polymorphism. J. Dairy Sci. 87:2606-2613.

Chianese, L., P. Ferranti, G. Garro, R. Mauriello, and F. Addeo. 1997. Occurrence of three novel $\alpha_{\mathrm{s} 1}$-casein variants in goat milk. Pages 259-267 in Proc. Intl. Dairy Fed. Seminar, Palmerston North, New Zealand. IDF Special Issue 9702, Milk Protein Polymorphism. International Dairy Federation, Brussels, Belgium.

Chiatti, F., S. Chessa, P. Bolla, G. Cigalino, A. Caroli, and G. Pagnacco. 2007. Effect of $\kappa$-casein polymorphism on milk composition in the Orobica goat. J. Dairy Sci. 90:1962-1966.

Chilliard, Y., J. Rouel, and C. Leroux. 2006. Goat's alpha-s1 casein genotype influences its milk fatty acid composition and delta-9 desaturation ratios. Anim. Feed Sci. Technol. 131:474-487.

Clark, S., and J. W. Sherbon. 2000. Alpha $\mathrm{s}_{\mathrm{s} 1}$-casein, milk composition and coagulation properties of goat milk. Small Rumin. Res. 38:123-134.

Cole, C., J. D. Barber, and G. J. Barton. 2008. The Jpred 3 secondary structure prediction server. Nucleic Acids Res. 36(Web Server issue):W197-W201.

Criscione, A., I. Comi, R. A. Inglingstad, D. Marletta, B. Valenti, T. Devold, and G. Vegarud. 2011. Identification and quantification of goat milk proteins. Poster presented at IDF International Symposium on Sheep, Goat and Other Non-Cow Milk, May 16-18, 2011, Athens, Greece.

Dagnachew, B. S., G. Thaller, S. Lien, and T. Ådnøy. 2011. Casein SNP in Norwegian goats: Additive and dominance effects on milk composition and quality. Genet. Sel. Evol. 43:31.

Dalgleish, D. G. 2011. On the structural models of bovine casein micelles-review and possible improvements. Soft Matter 7:22652272 .

de Kruif, C. G., T. Huppertz, V. S. Urban, and A. V. Petukhov. 2012. Casein micelles and their internal structure. Adv. Colloid Interface Sci. $171-172: 36-52$.

De Noni, I. 2008. Release of $\beta$-casomorphins 5 and 7 during simulated gastro-intestinal digestion of bovine $\beta$-casein variants and milkbased infant formulas. Food Chem. 110:897-903.

Devold, T. G., M. J. Brovold, T. Langsrud, and G. E. Vegarud. 2000. Size of native and heated casein micelles, content of protein and minerals in milk from Norwegian Red cattle-Effect of milk protein polymorphism and different feeding regimes. Int. Dairy J. 10:313-323.
Devold, T. G., R. Nordbø, T. Langsrud, C. Svenning, M. Jansen Brovold, E. S. Sørensen, B. Christensen, T. Ånnøy, and G. E. Vegarud. 2010. Extreme frequencies of the os1-casein "null" variant in milk from Norwegian dairy goats-Implications for milk composition, micellar size and renneting properties. Dairy Sci. Technol. 91:39-51.

Fomichev, K. A., A. L. Sazanova, T. Malewski, S. Kaminski, and A. A. Sazanov. 2012. Associations between two novel rSNPs in 5'-flanking region of the bovine casein gene cluster and milk performance traits. Gene 496:49-54.

Glantz, M., T. G. Devold, G. E. Vegarud, H. Lindmark Månsson, H. Stålhammar, and M. Paulsson. 2010. Importance of casein micelle size and milk composition for milk gelation. J. Dairy Sci. 93:1444-1451.

Gómez-Ruiz, J. Á., B. Miralles, P. Agüera, and L. Amigo. 2004. Quantitative determination of $\alpha_{\mathrm{s} 2^{-}}$and $\alpha_{\mathrm{s} 1^{-}}$-casein in goat's milk with different genotypes by capillary electrophoresis. J. Chromatogr. A $1054: 279-284$

Gordon, D., C. Abajian, and P. Green. 1998. Consed: A graphical tool for sequence finishing. Genome Res. 8:195-202.

Greyling, J. P. C., V. M. Mmbengwa, L. M. J. Schwalbach, and T. Muller. 2004. Comparative milk production potential of indigenous and Boer goats under two feeding systems in South Africa. Small Rumin. Res. 55:97-105.

Grosclaude, F., M.-F. Mahé, G. Brignon, L. Di Stasio, and R. Jeunet. 1987. A Mendelian polymorphism underlying quantitative variations of goat $\alpha_{\mathrm{S} 1}$-casein. Genet. Sel. Evol. 19:399-412.

Guo, M. R., P. H. Dixon, Y. W. Park, J. A. Gilmore, and P. S. Kindstedt. 2001. Seasonal changes in the chemical composition of commingled goat milk. J. Dairy Sci. 84(E. Suppl.):E79-E83.

Hayes, B., N. Hagesæther, T. Ådnøy, G. Pellerud, P. Berg, and S. Lien. 2006. Effects on production traits of haplotypes among casein genes in Norwegian goats and evidence for a site of preferential recombination. Genetics 174:455-464.

Heck, J. M. L., C. Olieman, A. Schennink, H. J. F. van Valenberg, M. H. P. W. Visker, R. C. R. Meuldijk, and A. C. M. van Hooijdonk. 2008. Estimation of variation in concentration, phosphorylation and genetic polymorphism of milk proteins using capillary zone electrophoresis. Int. Dairy J. 18:548-555.

Heck, J. M. L., H. J. F. van Valenberg, J. Dijkstra, and A. C. M. van Hooijdonk. 2009. Seasonal variation in the Dutch bovine raw milk composition. J. Dairy Sci. 92:4745-4755.

IDF-ISO-AOAC (International Dairy Federation-International Organization for Standardization-AOAC International). 2005. Solids (total) in milk by direct forced air oven drying. AOAC Official Method 990.20. AOAC International, Washington, DC.

ISO and IDF (International Organization for Standardization and International Dairy Federation). 2001. Milk-Determination of nitrogen content-Part 1: Kjeldahl method. ISO 8968-1, IDF 20-1. ISO, Geneva, Switzerland.

Jenness, R., and J. Koops. 1962. Preparation and properties of a salt solution which simulates milk ultrafiltrate. Neth. Milk Dairy J. $16: 153-164$.

Jordana, J., M. Amills, E. Diaz, C. Angulo, J. M. Serradilla, and A. Sanchez. 1996. Gene frequencies of caprine $\alpha_{\mathrm{s} 1}$-casein polymorphism in Spanish goat breeds. Small Rumin. Res. 20:215-221.

Küpper, J., S. Chessa, D. Rignanese, A. Caroli, and G. Erhardt. 2010. Divergence at the casein haplotypes in dairy and meat goat breeds. J. Dairy Res. 77:56-62.

Marletta, D., A. Criscione, S. Bordonaro, A. M. Guastella, and G. D'Urso. 2007. Casein polymorphism in goat's milk. Lait 87:491504

Marletta, D., S. Bordonaro, A. M. Guastella, A. Criscione, and G. D'Urso. 2005. Genetic polymorphism of the calcium sensitive caseins in Sicilian Girgentana and Argentata dell'Etna goat breeds. Small Rumin. Res. 57:133-139.

Martin, P., and C. Leroux. 1994. Characterization of a further $\alpha_{\mathrm{s} 1^{-}}$ casein variant generated by exon skipping. Page 88 in Proc. 24th International Technical Conference on Animal Genetics, International Society for Animal Genetics (ISAG), Prague, Czech Republic. 
Martin, P., M. Ollivier-Bousquet, and F. Grosclaude. 1999. Genetic polymorphism of caseins: A tool to investigate casein micelle organization. Int. Dairy J. 9:163-171.

Martin, P., M. Szymanowska, L. Zwierzchowski, and C. Leroux. 2002. The impact of genetic polymorphisms on the protein composition of ruminant milks. Reprod. Nutr. Dev. 42:433-459.

Merriman, T. R. 2009. Type 1 diabetes, the A1 milk hypothesis and vitamin D deficiency. Diabetes Res. Clin. Pract. 83:149-156.

Mestawet, T. A., A. Girma, T. Ådnøy, T. G. Devold, J. A. Narvhus, and G. E. Vegarud. 2012. Milk production, composition and variation at different lactation stages of four goat breeds in Ethiopia. Small Rumin. Res. 105:176-181.

Moatsou, G., E. Moschopoulou, D. Mollé, V. Gagnaire, I. Kandarakis, and J. Léonil. 2008. Comparative study of the protein fraction of goat milk from the Indigenous Greek breed and from international breeds. Food Chem. 106:509-520.

Moatsou, G., M. Samolada, P. Panagiotou, and E. Anifantakis. 2004. Casein fraction of bulk milks from different caprine breeds. Food Chem. 87:75-81.

Moioli, B., M. D'Andrea, and F. Pilla. 2007. Candidate genes affecting sheep and goat milk quality. Small Rumin. Res. 68:179-192.

Morand-Fehr, P., V. Fedele, M. Decandia, and Y. Le Frileux. 2007. Influence of farming and feeding systems on composition and quality of goat and sheep milk. Small Rumin. Res. 68:20-34.

Nickerson, D. A., V. O. Tobe, and S. L. Taylor. 1997. PolyPhred: Automating the detection and genotyping of single nucleotide substitutions using fluorescence-based resequencing. Nucleic Acids Res. 25:2745-2751.

O'Connell, J. E., and P. F. Fox. 2000. The two-stage coagulation of milk proteins in the minimum of the heat coagulation time-pH profile of milk: Effect of casein micelle size. J. Dairy Sci. 83:378-386.

O'Donnell-Megaro, A. M., D. M. Barbano, and D. E. Bauman. 2011 Survey of the fatty acid composition of retail milk in the United States including regional and seasonal variations. J. Dairy Sci. 94:59-65.

Ollier, S., S. Chauvet, P. Martin, Y. Chilliard, and C. Leroux. 2008 Goat's $\alpha_{S 1}$-casein polymorphism affects gene expression profile of lactating mammary gland. Animal 2:566-573.

Ouweltjes, W., B. Beerda, J. J. Windig, M. P. L. Calus, and R. F. Veerkamp. 2007. Effects of management and genetics on udder health and milk composition in dairy cows. J. Dairy Sci. 90:229238

Park, Y. W., M. Juárez, M. Ramos, and G. F. W. Haenlein. 2007. Physico-chemical characteristics of goat and sheep milk. Small Rumin. Res. 68:88-113.

Pierre, A., F. Michel, and Y. Le Graet. 1995. Variation in size of goat milk casein micelles related to casein genotype. Lait 75:489-502.

Pierre, A., F. Michel, and L. Zahoute. 1999. Composition of casein micelles in relation to size in goat milks with $\mathrm{A}$ and null $\alpha_{\mathrm{s} 1}$-casein variants. Int. Dairy J. 9:179-182.

Prinzenberg, E.-M., K. Gutscher, S. Chessa, A. Caroli, and G. Erhardt. 2005. Caprine k-casein (CSN3) polymorphism: New developments in molecular knowledge. J. Dairy Sci. 88:1490-1498.

Ramunno, L., G. Cosenza, A. Rando, R. Illario, D. Gallo, D. Di Berardino, and P. Masina. 2004. The goat $\alpha_{\mathrm{s} 1}$-casein gene: Gene structure and promoter analysis. Gene 334:105-111.
Ramunno, L., G. Cosenza, A. Rando, A. Pauciullo, R. Illario, D. Gallo, D. Di Berardino, and P. Masina. 2005. Comparative analysis of gene sequence of goat CSN1S1 $\mathrm{F}$ and $\mathrm{N}$ alleles and characterization of CSN1S1 transcript variants in mammary gland. Gene 345:289-299.

Rekik, B. 2012. Studies on some reproduction and production traits of Boer goats and their crosses at Hawassa University, Ethiopia. MS Thesis. School of Animal and Range Sciences, Hawassa University, Hawassa, Ethiopia.

Ribeiro, A. C., J. F. Lui, S. A. Queiroz, S. D. A. Ribeiro, and K. T. Resende. 2000. Milk yield, genetic trends and genetic and phenotypic parameters estimates for milk yield and lactation length of Saanen goats in Brazil. Pages 242-243 in Proc. 7th Intl. Conf. Goats, Tours, France. Institut de l'Élevage, Paris, France.

Sacchi, P., S. Chessa, E. Budelli, P. Bolla, G. Ceriotti, D. Soglia, R. Rasero, E. Cauvin, and A. Caroli. 2005. Casein haplotype structure in five Italian goat breeds. J. Dairy Sci. 88:1561-1568.

Sevi, A., L. Taibi, M. Albenzio, A. Muscio, and G. Annicchiarico. 2000. Effect of parity on milk yield, composition, somatic cell count, renneting parameters and bacteria counts of Comisana ewes. Small Rumin. Res. 37:99-107.

Soryal, K., F. A. Beyene, S. Zeng, B. Bah, and K. Tesfai. 2005. Effect of goat breed and milk composition on yield, sensory quality, fatty acid concentration of soft cheese during lactation. Small Rumin. Res. 58:275-281.

Stoop, W. M., H. Bovenhuis, J. M. L. Heck, and J. A. M. van Arendonk. 2009. Effect of lactation stage and energy status on milk fat composition of Holstein-Friesian cows. J. Dairy Sci. 92:1469-1478.

Tadlaoui Ouafi, A., J.-M. Babilliot, C. Leroux, and P. Martin. 2002 Genetic diversity of the two main Moroccan goat breeds: Phylogenetic relationships with four breeds reared in France. Small Rumin. Res. 45:225-233.

Talpur, F. N., M. I. Bhanger, A. A. Khooharo, and G. Z. Memon 2008. Seasonal variation in fatty acid composition of milk from ruminants reared under the traditional feeding system of Sindh, Pakistan. Livest. Sci. 118:166-172.

Thomann, S., A. Brechenmacher, and J. Hinrichs. 2008. Strategy to evaluate cheesemaking properties of milk from different goat breeds. Small Rumin. Res. 74:172-178.

Tziboula, A., and D. S. Horne. 1999. The role of $\alpha_{\mathrm{s} 1}$-casein in the structure of caprine casein micelles. Int. Dairy J. 9:173-178.

Vacca, G. M., H. O. A. B. Ali, V. Carcangiu, M. Pazzola, and M. L. Dettori. 2009. Genetic structure of the casein gene cluster in the Tunisian native goat breed. Small Rumin. Res. 87:33-38.

Valenti, B., R. I. Pagano, and M. Avondo. 2012. Effect of diet at different energy levels on milk casein composition of Girgentana goats differing in CSN1S1 genotype. Small Rumin. Res. 105:135-139.

Yasmin, A., N. Huma, M. S. Butt, T. Zahoor, and M. Yasin. 2012. Seasonal variation in milk vitamin contents available for processing in Punjab, Pakistan. J. Saudi Soc. Agric. Sci. 11:99-105.

Zullo, A., C. M. A. Barone, L. Chianese, P. Colatruglio, M. Occidente, and D. Matassino. 2005. Protein polymorphisms and coagulation properties of Cilentana goat milk. Small Rumin. Res. 58:223-230. 


\section{APPENDIX}

Table A1. An overview of genotypes across breeds and milk characteristics observed on the principal components (PC) plot

\begin{tabular}{|c|c|c|c|c|c|c|c|c|c|c|}
\hline Breed & Genotype $^{1}$ & \multicolumn{2}{|c|}{ Letters used $^{2}$} & \multicolumn{7}{|c|}{ Milk characteristics } \\
\hline Somali & New mutation & $\mathrm{CC}$ & SN & 19.1 & 7.5 & 14.9 & 3.9 & 25.8 & 13.6 & 175.4 \\
\hline Boer & Reference & $\mathrm{AA}$ & $\mathrm{BR}$ & 13.6 & 4.4 & 7.6 & 2.6 & 15.7 & 9.2 & 236.5 \\
\hline Arsi-Bale cross & Heterozygote & $\mathrm{CA}$ & $\mathrm{AHZ}$ & 18.5 & 5.2 & 8.5 & 3.6 & 16.4 & 9.7 & 237.9 \\
\hline
\end{tabular}

${ }^{1}$ New mutation $=$ goats carrying the new mutation $(\mathrm{CC})$; reference $=$ goats carrying the reference genotype $(\mathrm{AA})$; heterozygote $=$ goats carrying both alleles (CA): they are crossbred goats between either Boer and Arsi-Bale or Boer and Somali.

${ }^{2}$ Nucleotide in the text $=$ the nucleotides at the mutation position 10657 of CSN1S1; abbreviation on the plot = the first letter represents the breed and the second or the second and the third represent the type of mutation the goats carry; AN = Arsi-Bale new mutation; SN = Somali new mutation; $\mathrm{BR}=$ Boer reference; $\mathrm{AHZ}=$ Arsi-Bale heterozygote cross; $\mathrm{SHZ}=$ Somali heterozygote cross . 